\title{
Clemens of the 'Call'
}

Mark Twain in San Francisco

\section{Edited by Edgar M. Branch}

When Samuel Clemens was the local reporter for the San Francisco Daily Morning Call in 1864, he wrote hundreds of items for his newspaper, nearly all of which have been buried in the files ever since. Clemens of the ' Call' reprints two hundred of them in a volume that students of Mark Twain's stylistic development will find of lively interest. The selections appear in chronological order within broad topical groupings, thus revealing the main categories of Clemens' reporting, and clarifying the continuities in his treatment of specific subjects and personal concerns. Mr Branch indicates the evidence that in his opinion establishes Clemens as the author of the reprinted selections.

1969 LC: $69-15084336$ pages illustrations \$10.00

\section{from California}

University of California Press - Berkeley 94720

Marshall Lectures 1967-8

\section{Marshall, Marx and Modern Times}

\section{The Multi-dimensional Society}

\section{CLARK KERR}

A discussion of the ideas of Alfred Marshall and Karl Marx, comparing their views on the role and eventual destiny of the working class in social evolution. Professor Kerr considers that contemporary society lies somewhere between 'the free market of Marshall and the "social plan" of Marx'. He looks for the 'inherent contradictions' within modern society and asks where the new areas of conflict lie. The essays end with a brief survey of the influence of the ideas of Marshall and Marx on society today.

$8^{\prime \prime} \times 5^{\prime \prime} ; 23 / 2 / 70136 \mathrm{pp}$.

\section{CAMBRIDGE UNIVERSITY PRESS}




\section{Preparing for Ulysses}

\section{Politics and Veterans During World War II}

BY DAVIS R. B. ROSS

Though historians have naturally focused their attention primarily on the international aspects of United States actions during World War II, the period was also very significant for American domestic developments. This study chronicles the significant alteration from earlier policies in the Federal Government's response to the needs of returning veterans. Extensive use has been made of government archives.

326 pages $90 \mathrm{~s}$

\section{The Law Practice of Alexander Hamilton}

\section{Documents and Commentary, volume II}

EDITED BY JULIUS GOEBEL, JR.

Although Alexander Hamilton is remembered chiefly for his public services to the nation, he actually spent most of his life in law practice. Presented here are his papers dealing with commercial transactions, marine insurance, and admiralty practice. These volumes constitute one of the few works on legal practice in the United States during the early years of independence.

978 pages $£ 1310 \mathrm{~s}$

\section{Utopia and Reality}

\section{A Collective Portrait of American Socialists}

BY BETTY YORBURG

By quoting and interpreting the views of thirty-four former and present leaders of the Socialist Party of America, Betty Yorburg reveals the significance of the movement in the lives of its adherents. They describe how they came to join the Party and how Party membership changed their lives; they give their views on themselves and the world in which they live, and their opinion of why socialism failed in America.

208 pages $67 s 6 d$

\section{Puritanism and the Wilderness}

The Intellectual Significance of the New England Frontier, 1629-1700 BY PETER N. CARROLL

This study examines the role of the wilderness in the thought of the settlers of New England. The novelty of the American situation impinged, at times subtly, at times brutally, on the founders of New England. The dialogue between the American environment and the European mind can be analysed in the context of the Puritan attitudes and responses to the wilderness.

256 pages $67 s 6 d$

\section{A Union of Individuals}

The Formation of the American Newspaper Guild, 1933-1936

BY DANIEL J. LEAB

Although scholarly and detailed, $A$ Union of Individuals will have a wide appeal to historians and journalists everywhere, dealing as it does with some of the most flamboyant characters who ever enlivened the labour movement. Daniel J. Leab recreates here not only the 'romance of newspapering' but examines in detail some of the major problems of the union and its era.

300 pages $90 \mathrm{~s}$

\section{COLUMBIA UNIVERSITY PRESS}

70 GREAT RUSSELL STREET, LONDON W.C. 1

(ii) 


\section{Frontier Settlement in Mexican California}

The Hijar-Padrés Colony and its Origins, 1769-1835

\section{by C. Alan Hutchinson}

Mr Hutchinson brings to life an unfamiliar chapter of Western history and sets forth some illuminating contrasts between Spanish, Mexican, and American attitudes and actions on their respective frontiers.

474 pages 90 s

\section{Strange Enthusiasm}

A Life of Thomas Wentworth Higginson by Tilden G. Edelstein

In this complete biography, Mr Edelstein illuminates the over-all problem of the American reformer and presents valuable new material about the organized militancy of abolitionists as they moved away from the non-violent methods of William Lloyd Garrison.

436 pages $99 \mathrm{~s}$

\section{Forging a Majority}

The Formation of the Republican Party in Pittsburgh, 1848-1860

by Michael Fitzgibbon Holt

Challenging the view that the politics of the pre-Civil War decade revolved around sectional conflicts over slavery and economic matters, Michael Holt suggests that the political coalitions of the day were more precisely a function of local social and economic dislocation resulting from industrialization and immigration.

418 pages 90 s

\section{Pilgrim Colony}

A History of New Plymouth, 1620-1691 by George D. Langdon, Jr.

'This first full-length, scholarly study of Plymouth is most welcome. It is a sound book, clearly and consistently devoted to the worthwhile purpose of locating the "Old Colony" in the broader stream of early New England history.'-John Demos, William and Mary Quarterly. 268 pages Paper 17s 6d

\section{Mining Engineers and the American West}

The Lace-Boot Brigade, 1849-1933 by Clark C. Spence

$\mathrm{Mr}$ Spence examines the professional mining engineer in terms of his education, life style, actual work, and impact upon the rugged environment beyond the Mississippi. He depicts the engineer's versatility in his several roles as manager of mines, consultant in the field and in the courtroom, and builder of financial empires, and traces the engineer's evolution from a generalist to a professional specialist. 400 pages illustrated $113 \mathrm{~s}$

\section{Prelude to Populism}

Origins of the Silver Issue, 1867-1878 by Allen Weinstein

Based upon the private papers, government records, and newspapers and journals of the period, Prelude to Populism is the first complete scholarly examination of the origins of the silver issue in post-Civil War America. 416 pages $90 \mathrm{~s}$

\section{Birth Control in America}

The Career of Margaret Sanger by David M. Kennedy

The author describes Mrs Sanger's great personal influence on the course of the birth control movement in the United States and examines those elements of her thought and character which shed light on the nature of twentieth-century feminism and reform. 320 pages $79 s$

\section{Wilderness and the American Mind}

by Roderick Nash

Roderick Nash outlines and interprets American attitudes toward wild country over three and a half centuries.

266 pages Paper 17s $6 d$

\section{Yale University Press}

70 Great Russell Street London WC1 


\section{BRITISH ASSOCIATION FOR AMERICAN STUDIES}

This Association was founded in 1955 to promote the study of the United States within the United Kingdom. It welcomes applications for membership from people interested in the history, society, government and politics, economics, geography, literature and thought of the United States. It publishes a Nerwsletter twice yearly, holds an Annual Conference, and provides other services for its members from time to time. Enquiries concerning current subscription rates and applications for membership should be addressed to the Secretary, Dr Charlotte Erickson, London School of Economics, Houghton Street, Aldwych, London, W.C. 2.

\section{NOTES FOR CONTRIBUTORS}

All contributions and editorial correspondence should be sent to the Editor, Journal of American Studies, Department of American Studies, The University, Manchester I3. Submission of an article is taken to imply that it has not previously been published, or is not being considered for publication elsewhere. Articles should generally contain about 5000 words, although longer articles may be submitted by agreement with the Editor. Contributors need not be members of the British Association for American Studies.

Contributions should be clearly typed in double spacing, preferably on quarto paper. Wide left-hand margins should be provided. Diagrams and maps may be included by arrangement with the Editor.

The rule about double-spacing applies also to footnotes. These should be inserted for the following purposes only:

(i) to give references for direct quotations used in the text;

(ii) to give references to the main authorities on disputable questions; and

(iii) to give evidence relied on by the contributor for any new or unusual conclusions.

General notes intended for the Editor and printer should be attached on a separate sheet. Contributors should keep one copy of the typescript for use in correcting proofs.

First proofs may be read and corrected by contributors provided that they can give the Editor an address through which they can be reached without delay and can guarantee to return the corrected proofs to the Editor, by airmail where appropriate, within ten days of receiving them. The master proof will always be sent direct to the Editor by the printer; contributors will receive duplicates.

Contributors of articles and review articles receive 25 free separates. Extra copies may be bought according to an agreed scale of charges. 


\section{JOURNAL OF AMERICAN STUDIES}

page I Hans R. GUGGisBerG

The Uses of the European Past in American Historiography

I9 JOHN RENWICK

Bélisaire in South Carolina, I768

39 Stuart Morris

The Wisconsin Idea and Business Progressivism

6i Nicolaus C. Mills

Social and Moral Vision in Great Expectations and Huckleberry Finn

73 Alan W. Bellinger

The Tragic Muse: the objective centre

9I M. GidLEY

Some notes on Faulkner's Reading

I03 Frank DURHAM

Hawthorne and Goldsmith: a Note

I07 Theses on American Topics in Progress and Completed at British Universities

123 BOOK REVIEWS

CAMBRIDGE UNIVERSITY PRESS

Bentley House, 200 Euston Road, London, N.W. I

American Branch: 32 East 57th Street, New York, N.Y. 10022

27 s. $6 d$. net; $\$ 4.50$ in U.S.A. Subscription price 40 s. net; $\$ 6.50$ in U.S.A. 